\title{
Menguji Konflik Peraturan Perundang-undangan Pusat dan Daerah
}

\author{
Samsul Wahidin
}

\begin{abstract}
Basically, only one legal system that served national interests. Yet, at this moment between Central Goverment and Local Govemment has tendecy to dochotomize administration law. Harmonization perspective of legal product between Central and Local Govemment should be focused as interreleted components besides that the law enforcement should be implementated in good manner.
\end{abstract}

\section{Pendahuluan}

Dewasa ini, ada kecenderungan mendikotomikan hukum administrasi, antara Pusat dan Daerah. Sesuai dengan komitmen terhadap Negara Kesatuan Indonesia, pada dasamya hanya ada satu sistem hukum, yaitu sistem hukum nasional yang mengabdi kepada kepentingan nasional. Produk hukum harus senantiasa berorientasi kepada kepentingan nasional sebagai refleksi dari komitmen Negara Kesatuan. Di dalam refleksi hukum, produk yang dapat dinilai bermasalah di daerah adalah Peraturan Daerah. Secara kelembagaan produk ini perlu dicermati dalam kaitannya dengan indikator terjadinya konflik peraturan perundangan baik yang sifatnya horisontal, apa lagi yang bersifat vertikal. ${ }^{1}$

Pada sisi lain, sebuah produk hukum -apakah itu mengandung muatan konflik vertikal maupun konflik horisontal, harus didasarkan pada asas presumption of inno-. cence- dan mau tidak mau mesti ada keputusan yang mempunyai kekuatan hukum tetap untuk menyatakannya. Sebuah analisis tidak dapat dengan begitu saja - dan secara parsial menyatakan bahwa suatu peraturan perundangan tingkat Daerah bertentangan dengan peraturan perundangan di atasnya

1Konfik horizontal maksudnya pertentangan antar peraturan perundangan yang sejenis (misalnya antara sesama Peraturan pemerintah, atau sesama Keputusan Presiden, ataus sesama Peraturan Daerah. Konflik vertikal maksudnya antara peraturan perundangan yang tingkatannya lebih rendah dengan peraturan yang tingkatannya lebih tinggi. Untuk ini, lebih lanjut lihat misalnya dalam Karl. Larenz, Methodenlehre der Rechtswissenschaft (Berlin: Springer Verlag, 1983) 
(dikeluarkan oleh Pusat). Konsistensi terhadap lembaga pengujian semestinya dicermati dan tidak semata meninjau dari perspektif non yuridis (misalnya dari sisi politis) yang menyebabkan adanya simpulan tidak sesuai dengan hukum.

Ada konstruksi yuridis yang kiranya perlu dicermati, sehubungan dengan "sinyalemen" itu konstruksi formal sebagaimana diatur di dalam Tap No: III/MPR/2000 tentang Sumber Hukum dan Tata Urutan Peraturan Perundangan. Ketetapan ini adalah merupakan penyempurnaan terhadap Tap No: XX/MPRS/1966 tentang Sumber Tertib Hukum dan Tata Urutan Peraturan Perundangan RI. Ketetapan ini, sesuai dengan konstruksi yuridis sistem negara Kesatuan harus dipandang sebagai refleksi pengaturan berbagai institusi, baik sosial maupun pemerintahan. Rujukan berbagai kebijakan tertulis harus tetap konsisten serta konsekuen pada ketatapan ini yang dipandang sebagai refleksi aspirasi rakyat.

\section{Produk Pusat-Daerah}

Sehubungan dengan euforia otonomi daerah, maka untuk landasan hukumnya adalah UU tentang Pemerintahan Daerah. Hubungan ini harus meyakini bahwa produk tersebut merupakan kompromistik yang telah mengakomodasikan berbagai kepentingan. Berbagai kepentingan dimaksud khususnya adalah antara Pusat dan Daerah yang selama ini dalam banyak kasus disikapi secara dikotomis. Sekurangnya produk hukum yang menjadi kesepakatan itu harus dijadikan sebagai landasan terpercaya. Tidak mengartikan dan atau menafsirkan berdasar kepentingan dan motivasi yang sejatinya bertentangan dengan hukum atau asas hukum. Jika hal ini yang dilakukan, maka akan selalu terjadi tarik-menarik dan memunculkan permasalahan baru yang sebenarnya dapat dihindakan. Tentu saja antara Pusat pada satu sisi dan Daerah pada sisi lain.

\section{Banjarmasin}

Asas Penyelenggaraan Pemerintahan Daerah, dengan memperbesar porsi asas desentralisasi dalam sistem pemerintahan daerah dalam peraturan perundangundangan di Indonesia mengalami pasang surut. Hubungannya dengan permasalahan lingkungan hidup begitu penting terutama sekali untuk mencermati seberapa besar kewenangan Pemerintah Daerah di dalam masalah ini sehingga dapat dilakukan penilaian pula apakah kewenangan tersebut mampu mengakomodasikan kebutuhan dan menjawab secara riil hal-hal yang muncul di. Daerah.

Sinkronisasi ${ }^{2}$ yang kiranya secara normatif harus dijadikan sebagai patokan dalam kerangka hubungan Pusat dan Daerah adalah bahwa hakekat hubungan antara PusatDaerah bukan sebagai sesuatu yang bersifat

2lihat: GJ. Viarda, Drie Typen van Rechtsvinding (Tṭ: Tjeenk Willink-Zwole, 1980), h/m. 82 pada bagian "Marginale Toetsing" menekankan sulitnya sinkronisasi dan akibat yang akan muncul jjka hal ini tidak dilaksanakan terutama berhubungan dengan prinsip atau asas legalitas yang menekankan pada keharusan pegangan pada hukum tertulis (peraturan perundang-undangan). 
dikotomis dan oleh karena itu tidak didikotomikan. Daerah bukanlah "koloni" dari Pusat dan pemerintah Pusat tidak berstatus sebagai "pangreh"3 atas segala sesuatu yang ada di daerah. Berdasar kerangka dalam UUD 1945 sistem negara Indonesia adalah kesatuan. Berdasar perspektif ini, otoritas dasar atas segala kekuasaan harus diposisikan pada proporsinya yaitu pada pemerintah Pusat sebagai refleksi dari Negara Kesatuan. Daerah dalam konteks ini adalah sebagai pemegang otoritas yang dilimpahkan oleh Pusat. Hal ini menjadi satu komitmen yang disarikan dari berbagai teori tentang ajaran rumah tangga dalam kerangka otonomi daerah yang senantiasa menjadi perbincangan hangat sampai sekarang.

Ketentuan di dalam Pasal 18 beserta amandemennya memberi kesan bahwa sistem Negara Kesatuan yang dijadikan patokan dasar memberikan keleluasaan kepada daerah sedemikian besar. Bahkan di dalam operasionalisasinya, sebagaimana dinyatakan dalam Undang-Undang tentang Pemerintahan Daerah (UU No. 22 Tahun 1999) hanya ada 5 (lima) sektor yang menjadi urusan Pusat yaitu Moneter, Pengadilan, Pertahanan Keamanan, Hubungan Luar Negeri dañ Agama. Pembatasan ini sebenamya dapat dikatakan sebagai substansi yang berlaku pula pada wacana negara federasi. Tak berlebihan jika ada yang menyatakan bahwa prinsip-prinsip dasar federasi sudah mulai diterapkan dalam sistem Pemerintahan Daerah di Indonesia.

Makna lebih operasional dari kenyataan di atas adalah harus diakomodasikannya fakta empirik di daerah sebagai refleksi dari pengakuan atas heterogenitas masyarakat Indonesia. Tentu saja dengan tidak meninggalkan prinsip bahwa sebagai konsekuensi Negara Kesatuan, maka apa pun yang menjadi perkecualian harus senantiasa mengabdi dan diabdikan kepada keutuhan Negara Kesatuan. Pola-pola dan kebijakan yang mencerminkan "perlawanan" dan penggarisan kebijakan yang tidak didasarkan atas prinsip ini tidak perlu ditempuh. Termasuk kebijakan yang didasarkan pda prinsip trial and error serta kebijakan yang dilandasi oleh penafsiran yang bersifat sepihak akan tetapi bertentangan dengan maksud dibentuknya UU tersebut. ${ }^{4}$

Di dalam refleksi Negara yang dijadikan sebagai prinsip dasar dengan label kesatuan tersebut, produk peraturan perundangundangan yang harus dijadikan sebagai acuan adalah sebagaimana dituangkan dalam Tap No:Ill/MPR/2000 di atas. Secara hirarkhis dinyatakan bahwa Tata Urutan

${ }^{3}$ Djenal Hosen Koesoemahatmadja, Pemerintahan Lokal (Bandung. Alumni, 1983), him. 31 yang menguraikan falsafah pangreh sebagai lembaga yang memimpin sementara pada pihak lain ada abdi atau yang dipimpin. Peletakan secara dikotomis ini yang kita nilai kurang tepat dengan mengingat bahwa prinsip antara pangreh dan yang di-reh adalah sederajat.

${ }^{4}$ Misalnya konfilik atau minimal ketaksamaan persepsi dalam hal pembangunan jalan kereta apai.(reahway) yang akan menghubungkan Tanjung (Kalsel) dan Pasir (Kaltim). Pemprov dengan berpegang pada PP No. 25 Tahun 2000 berpendapat bahwa itu kewenangannya. Kabupaten dengan dalih untuk pengembangan wilayah juga mendalilkan adanya hak yang sama. 
Peraturan Perundang-Undangan merupakan pedoman dalam pembuatan peraturan hukum di bawahnya. Tata urutan tersebut merupakan refleksi dari asas legalitas yang mendasari setiap pengambilan kebijakan. Secara berurutan dinyatakan bahwa peraturan perundangundangan $\mathrm{Rl}$ adalah:

\section{Undang Undang Dasar 1945 \\ Tap MPR \\ UU \\ Peratuan Pemerintah Pengganti UU (Perpu) \\ Peraturan Pemerintah \\ Keputusan Presiden \\ Peraturan Daerah. ${ }^{5}$}

Dibuatnya Tap No: III/MPR/2000 itu temyata menimbulkan kontroversi khususnya kedudukan dari Keputusan Menteri (Kepmen). Sehubungan dengan hal tersebut, Menteri Kehakiman dan HAM, Baharuddin Lopa mengirimkan surat kepada para Menteri dan Pimpinan Lembaga Negara Non Departemen (LPND) tertanggal 23 Februari 2001. Menkeh dan HAM menyatakan bahwa kedudukan Kepmen itu adalah di atas Peraturan Daerah (Perda) dan setingkat di bawah Keputusan Presiden (Keppres). Surat bernomor: M.UM.01.06-27 itu juga menyatakan bahwa Kepmen adalah merupakan produk hukum yang sifatnya mengatur (regeling) dan bukan semata-mata bersifat Keputusan (beschiking).
Kontroversi terhadap kedudukan Kepmen ini dapat dipandang sebagai refleksi dari ketidakcermatan dalam menyusun Peraturan Perundangan. Pada sisi lain juga dapat dipandang sebagai sebuah bentuk akomodasi terhadap praktik penyelenggaraan negara melalui produk hukum yang diharapkan dapat dilaksanakan secara luwes. Namun akibat praktisnya jelas, tarik ulur kewenangan khususnya antara Pusat pada satu sisi dan daerah pada sisi lainnya - yang selama ini masih dalam tahap menemukan bentuk menjadi semakin kabur. Untuk itu diperlukan kesamaan bahasa tentang dimanakah sebenarnya kedudukan Kepmen dalam Tata Urutan Peraturan Perundangan. Hal ini penting mengingat di dalam permasalahan lingkungan hidup banyak materi yang diatur di dalam Kepmen yang pada masa lalu senantiasa dirujuk sebagai dasar hukum untuk operasionalisasi berbagai permasalahan khususnya yang muncul di daerah.

Permasalahan berkenaan dengan kedudukan Kepmen itu muncul sebab di dalam Tap No: XX/MPRS/1966 yang diperbaiki dan disempumakan oleh Tap No: III/MPR 2000 tersebut mencantumkan Kepmen sebagai salah satu produknya. Kalau memang penyebabnya hanya karena judulnya adalah Keputusan, dan biasanya produk itu merupakan sebuah beschiking, mengapa ada Keppres dengan judul yang sama yaitu sama-sama Keputusan?

${ }^{5}$ Para pencermat menilai bahwa Tap No: III/MPR/2000 ini banyak kejanggalannya dan tidak cermat. Misalnya pada ketentuan Pasal 1 yang menyatakan bahwa sumber hukum adalah sumber yang dijadikan bahan untuk penyusunan peraturan perundang-undangan. Janggalnya, sumber hukum seharusnya tidak semata merujuk pada perundang-undangan. Tidak cermat, misalnya tidak ada produk hukum yang dikeluarkan oleh lembaga Kementerian Negara. Padahal produk hukum ini sangat penting untuk menjabarkan berbagai produk hukum di atasnya terutama peraturan pemerintah dan atau undang-undang. 
Mencermati penafsiran menurut tata bahasa (de grammaticale of taalkundige interpretatie) ${ }^{6}$ dari ketentuan di dalam Tap No: III/MPR/2000 itu dapat disimpulkan bahwa Kepmen memang tidak dimasukkan sebagai salah satu produk yang bersifat regeling. Dinyatakan dalam ketentuannya bahwa Peraturan dan Keputusan Mahkamah Agung, Badan Pemeriksa Keuangan, Menteri, Bank Indonesia, badan, Lembaga atau Komisi yang setingkat yang dibentuk oleh pemerintah tidak boleh bertentangan dengan ketentuan yang termuat dalam Tata Urutan Peraturan Perundang-undangan (Pasal 4 ayat (2)). Hal ini berarti bahwa penyebutan produk hukum di dalam Tap tersebut sifatnya limitatif tidak enunsiatif.' Urut-urutan yang disebut di dalamnya pun sudah disebut secara jelas yaitu mulai dari Undang-Undang Dasar 1945, Tap MPR, Undang Undang, Perpu (Peraturan Pemerintah Pengganti Unang Undang), Peraturan Pemerintah, Keppres (Keputuan Presiden) dan Peraturan Daerah (Perda).

Berdasarkan tata urutan yang bersifat limitatif tersebut harus dimaknai bahwa di luar ke 7 (tujuh) produk hukum sebagaimana disebutkan berkualifikasi sebagai policy (kebijakan) yang berorientasi pada dua hal. Pertama, hanya merupakan sebuah beschiking yang tidak boleh mengikat umum dalam arti hanyalah sebagai kebijakan yang bersifat internal. Kedua, kalaupun merupakan bentuk produk yang bersifat pengaturan (regeling) harus senantiasa mengacu pada tata urutan (sesuai dengan klausula bahwa setiap aturan hukum yang lebih rendah tingkatannya tidak boleh bertentangan dengan aturan hukum yang lebih tinggi —vide Pasal 4 ayat (1)). Dengan demikian ketujuh produk itu sifatnya baku, final dan tidak boleh disimpangi.

Di dalam masalah Kepmen berhadapan dengan Keppres kiranya sudah jelas bahwa kedudukan Keppres lebih tinggi dari Kepmen. Hal ini disebabkan secara struktural kedudukan kedudukan Menteri lebih rendah dari presiden, atau konkritnya Menteri adalah pembantu Presiden. Konsekuensinya bahwa setiap produk hukum yang dibuat oleh Menteri tidak boleh bertentangan bahkan harus senantiasa merujuk pada materi yang menjadi muatan Keppres. Kalau ada pertentangan antara Keppres dengan Kepmen maka Keppres harus dijadikan sebagai patokan sesuai dengan asas lex superior derogat legi priori.

Menyoal kedudukan Kepmen berhadapan dengan Perda, dapat dicermati berdasarkan kelembagaan. Pada masa lalu kelembagaan Menteri sebagai pembantu presiden berkedudukan lebih tinggi dari Pemerintah Daerah. Menteri berkedudukan sebagai "atasan" dari Pemda, dalam arti Menteri adalah pejabat Pusat sedangkan Daerah adalah "bawahan" Pusat yang hampir sepenuhnya tergantung pada pengaturan dan hal-hal yang bersifat instruktif dari Pusat.

BJ.A. Pontier, Rechtsvinding (Nijmegen: Ars Aequi Libri, 1988), hlm. 22.

'Limitatif artinya terstruktur, tidak dapat disimpangi-berdasar asas hukum yang dijadikan sebagai pijakan seperti lex superior derogat legi prioridan lex specialis derogat legigenerali. Demikian pula bersifat hirarkhis dalam arti tidak dapat disimpangi dalam hal kedudukannya berdasarkan kelembagaan yang mengeluarkan produk. Enunsiatif artinya dapat saja disimpangi atau bersifat relatif, dengan logika hukum yang dapat dipertanggungjawabkan dalam arti berdasarkan prinsip-prinsip hukum. 
Kendatipun ada otonomi daerah tetapi praktiknya lebih bersifat sentralistik yang diterapkan untuk dan atas nama kesatuan dan persatuan. Hal ini dapat dicermati pada berbagai praktik penyelenggaraan pemerintahan, seperti adanya lembaga-lembaga Pusat yang adadi daerah, pembiayaan yang besar berasal dari Pusat.

Sejalan dengan paradigma otonomi daerah yang baru berdasarkan UU No. 22 Tahun 1999, konsep yang ingin diterapkan adalah bersifat fungsional dengan meletakkan hubungan Pusat dan Daerah bersifat fungsional. Pusat dan Daerah tidak diletakkan padá struktur atasan dan bawahan akan tetapi lebih pada fungsi masing-masing. Oleh karena itu menteri bukan atasan dari Pemerintah Daerah. Kalaupun ada hubungan antara Menteri dengan Pemerintah Daerah harus dimaknai secara fungsional -karena Kementerian adalah perangkat teknis (sesuai dengan bidang masing-masing) dari lembaga Kepresidenan. Dengan demikian produk hukum dari Menteri (berupa Kepmen) tidak dapat dipandang sebagai atasan dari Perda.

Kewenangan untuk itu pun sudah diatur lebih teknis di dalam Peraturan pemerintah (PP) No. 25 Tahun 2000 -dan untuk permasalahan lingkungan hidup sebagaimana akan disebut di bawah. Oleh karena itu produk hukum berupa Kepmen tidak boleh bertentangan dengan Perda. Kalau terjąi demikian maka yang harus dijadikan patokan adalah Perda dengan catatan tentunya bahwa Perda terebut mengacu dengan benar kepada produk hukum yang disebut oleh Tap No:.II/MPR/2000. Harus diakui bahwa Tap itu memang mengandung kelemahan baik struktural maupun fungsional. Alternatif yang dapat ditempuh untuk mengatasinya, pertama, dengan memperbaiki kembali Tap No: IIII MPR/2000 dengan memasukkan Kepmen sebagai salah satu produk hukum -dengan materi mengakomodasikan Surat Menteri Kehakiman dan HAM di atas. Secara praktis dapat dipahami karena Kepmen secara substansial dibutuhkan untuk mengatur lebih lanjut delegasi wewenang yang disebut oleh Undang-Undang, Peraturan Pemerintah maupun Keppres sendiri sesuai dengan lingkup kewenangan Menteri yang bersangkutan.

Kedua, secara konsisten tetap menjadikan Kepmen sebagai beschiking, berarti tidak perlu merubah Tap No: II/MPR/2000. Komitmen yang harus senantiasa dipegang adalah bahwa produk terendah yang boleh dijadikan sebagai dasar adalah Keppres. Kendatipun (mungkin) hanya bersifat sektoral akan tetapi tidak boleh mempergunakan Kepmen dan harus tetap pada produk yang disebut oleh Tap No: IIII MPR/2000. Dengan demikian diharapkan terwujudnya koordinasi dan sinkronisasi yang lebih baik baik dari segi materi maupun dari segi kelembagaan.

Terlepas dari kelemahan yang dijadikan sebagai konstruksi dan materi Tap No: III/MPRI $2000 \mathrm{di}$ atas, diakui bahwa di dalam penyelenggaraan pemerintahan khususnya peraturan perundang-undangan selama ini muncul kerancuan baik secara horizontal maupun vertikal. Secara horizontal yaitu dengan tidak terselenggaranya sinkronisasi antara peraturan yang selevel. Muncul kecenderungan egosektoral terhadap produk hukum khususnya pada level Undang Undang. Sementara itu secara vertikal juga masih banyak terjadi mis-sinkronisasi antara peraturan pada tingkat Pusat dan peraturan di Daerah. Hal itu pada akhimya juga menciptakan 
kondisi ketidakteraturan peraturan perundangundangan di dalam kinerja hukum.

Secara hirarkhis, telah diketahui adanya urutan khususnya dalam hal kewenangan dalam permasalahan otonomi daerah, mulai dari UUD 1945 sampai dengan Undang Undang yaitu UU No. 22 Tahun 1999 tentang Pemerintahan Daerah beserta dengan UU lain yang mendukungnya. UU itu harus dipandang sebagai pelaksanaan dari ketentuan yang ada di dalam UUD 1945 dimaksud dan karena itu harus pula secara konsisten dijadikan sebagai dasar pengambilan kebijakan. Tidak ada alternatif yang memungkinkan terjadinya penyimpangan terhadap konstruksi yuridis ini sehingga tidak diperlukan penafsiran yang justru akan meruwetkan permasalahan.

\section{Pengujian Produk Daerah}

Sinkronisasi terhadap produk Daerah dengan produk dari Pusat harus didasarkan pada ketentuan yang ada di dalam Tap No: III/ MPR/2000. Pertama, ketentuan di dalam Pasal 18 UUD 1945 yang berbunyi: Pembagian daerah Indonesia atas daerah besar dan kecil dengan bentuk susunan pemerintahannya ditetapkan dengan Undang Undang dengan memandang dan mengingat dasar permusyawaratan dalam sistem pemerintahan negara dan hakasal-usul dalam daerahdaerah yang besifat istimewa.

Penjelasan Pasal 18 di atas semakin memperkukuh makna dari keharusan mengedepankan prinsip Negara Kesatuan pada klausula bahwa oleh karena Indonesia itu suatu eenheidsstaat, maka Indonesia tidak akan mempunyai daerah di dalam lingkungannya yang bersifat staat juga. Hal ini berarti kendatipun makna otonomi daerah pada dasamya adalah kemandirian akan tetapi prinsip negara kesatuan harus dikedepankan. Otonomi daerah harus tunduk pada prinsipprinsip kesatuan yang melegalisasi otoritas pemerintahan tertinggi pada pemerintah pusat dan daerah menjadi kawasan administratif dalam arti kewenangannya tidak boleh bertentangan dengan kewenangan Pusat.

Ketentuan sebagaimana disebut di atas berlaku selama 55 tahun, yaitu sejak diberlakukannya UUD 1945 tanggal 18 Agustus 2000 saat ketentuan tersebut diamandemen oleh MPR. Amandemen Pasal 18 UUD 1945 yang dilakukan tahun 2000 membawa perubahan signifikan terhadap tatanan - dan berarti pemaknaan terhadap otonomi daerah. Perubahan tersebut bahkan mendeskripsikan pada segi-segi yang dapat dikualifikasikan teknis. Pasal 18 yang menekankan pada prinsip eenheidsstaat berhadapan dengan otonomi daerah pada Pasal 18 di atas dihapus dan diganti dengan ketentuan sebagai berikut:

1. Negara Kesatuan Republik Indonesia dibagi atas daerah-daerah provinsi, daerah kabupaten dan daerah provinsi itu dibagi atas kabupaten dan kota, yang tiaptiap provinsi, kabupaten dan kota itu mempunyai pemerintahan daerah, yang diatur di dalam Undang Undang.

2. Pemerintahan daerah provinsi, daerah kabupaten dan kota mengatur dan mengurus sendiri urusan pemerintahan menurut asas otonomi dan tugas pembantuan.

3. Pemerintahan daerah provinsi, daerah kabupaten dan kota memiliki Dewan Perwakilan rakyat Daerah yang anggotaanggotanya dipilih melalui pemilihan umum. 
4. Gubernur, Bupati dan Walikota masingmasing sebagai kepala pemerintahan daerah provinsi, kabupaten dan kota dipilih secara demokratis.

5. Pemerintahan daerah menjalankan otonomi seluas-luasnya, kecuali urusan pemerintahan yang oleh Undang Undang ditentukan sebagai urusan pemerintah pusat.

6. Pemerintahan Daerah berhak menetapkan Peraturan Daerah dan peraturanperaturan lain untuk melaksanakan otonomi dan tugas pembantuan.

7. Susunan dan tata cara penyelenggaraan pemerintahan daerah diatur dalam Undang-Undang.

Hubungan antara Pemerintah Pusat dan Pemerintah Daerah sebagai refleksi otonomi daerah diatur dalam Pasal 18A yaitu:

1. Hubungan wewenang antara pemerintah pusat dan pemerintah daerah provinsi, kabupaten dan kota atau antara provinsi dan kabupaten dan kota, diatur dengan undang-undang dengan memperhatikan kekhususan dan keragaman daerah.

2. Hubungan keuangan, pelayanan umum, pemanfaatan sumber daya alam dan sumber daya lainnya antara pemerintah pusat dan pemerintahan daerah diatur dan dilaksanakan secara adil dan selaras berdasarkan undang-undang.

Pemaknaan terhadap otonomi di atas dapat disebut sebagai "standar", sementara ada otonomi yang sifatnya khusus sebagaimana diatur di dalam Pasal $18 \mathrm{~B}$ yang menyatakan:

1. Negara mengakui dan menghormati satuan-satuan pemerintahan daerah yang bersifat khusus atau bersifat istimewa yang diatur dengan Undang -Undang.

2. Negara mengakui dan menghormati kesatuan-kesatuan masyarakat hukum adat beserta hak-hak tradisionalnya sepanjang masih hidup dan sesuai dengan perkembangan masyarakat dan prinsip Negara Kesatuan RI yang diatur dalam Undang-Undang.

Sesuai dengan hirarkhi peraturan perundang-undangan (vide Tap No: III/MPR 2000) dasar hukum yang harus dijadikan sebagai pijakan dalam pelaksanaan otonomi daerah adalah Tap No: IV/MPR/2000 tentang Rekomendasi Kebijakan dalam Penyelenggaraan Otonomi Daerah. Kendatipun di dalam Tap tentang GBHN juga disebut adanya pembangunan daerah akan tetapi untuk GBHN dipandang sebagai petunjuk teknis bagi presiden selaku Kepala Pemerintahan. Untuk dasar pijakan dalam pelaksanannya, Tap No: IV kiranya harus djjadikan sebagai penjabaran dari ketentuan Pasal 18 UUD 1945.

Keluamya Tap ini didasari atas penilaian terhadap penyelenggaraan otonomi daerah yang selama ini belum dilaksanakan secara baik dalam arti belum diberdayakan di atas prinsip keadilan dan perimbangan yang benar. dalam masalah keuangan. Penanganan otonomi daerah dinilai telah gagal dengan implikasi timbulnya ketidakpuasan dan ketersinggungan rasa keadilan seperti tercermin dalam tuntutan untuk memisahkan diri serta tuntutan agar otonomi daerah dilaksanakan secara benar.

Titik berat kebijakan otonomi daerah itu dilaksanakan untuk sasaran tertentu yaitu:

1. peningkatan pelayanan publik dan pengembangan kreativitas masyarakat serta aparatur pemerintahan di daerah. 
2. Kesetaraan hubungan antara pemerintah pusat dengan pemerintah daerah dan antar pemerintah daerah dalam kewenangan dan keuangan.

3. Untuk menjamin peningkatan rasa kebangsaan, demokrasi dan kesejahteaan masyarakat di daerah.

4. Menciptakan ruang yang lebih luas bagi kemandirian daerah.

Ketetapan ini dapat disebut sebagai bagian tak terpisahkan sekaligus sebagai penjelas pada level kebijakan dasar terhadap Tap No: XV/MPR/1998 tentang Penyelenggaraan Otonomi Daerah, Pengaturan, Pembagian dan Pemanfaatan Sumber Daya Nasional yang Berkeadilan serta Perimbangan Keuangan Pusat dan Daerah dalam Kerangka Negara Kesatuan Republkik Indonesia. Ketetapan ini tetap dijadikan sebagai acuan dasar dan menjadi bagian integral dari pelaksanaan administrasi pemerintahan dan masalah lain yang berkait erat dengan pemberdayaan masyarakat serta potensi yang ada di daerah.

Tataran yuridis berikutnya setelah Tap MPR adalah Undang Undang. Pada level ini, yang menjadi acuan adalah UU No. 22 Tahun 1999 sebagai pengganti dari UU No. 5 Tahun 1974. UU ini adalah sebagai UU Organik dari ketentuan yang disebutkan di dalam UUD 1945 tentang Pemerintahan Daerah. UU inj memberikan proteksi terhadap pelaksanaan otonomi daerah berdasarkan prinsip-prinsip yang dinilai benar berdasarkan ketentuan di dalam Undang-Undang Dasar 1945. Pelaksanaan UU itu ditunjang pula oleh perangkat UU lain seperti Perimbangan Keuangan antara Pusat dan Daerah, UU tentang Pemberantasan $\mathrm{KKN}$, yang kesemuanya bertujuan untuk lebih memberdayakan potensi yang ada di daerah. Pada tataran setelah Undang-Undang adalam Peraturan Pemerintah sebagai pelaksanaan Undang-Undang. Peraturan Pemerintah (PP) dimaksud adalah PP No. 25 Tahun 2000 tanggal 6 Mei 2000 tentang Kewenangan Pemerintah dan Kewenangan Provinsi sebagai Daerah Otonom.

Di dalam ketentuan ini barulah ada ketentuan yang mengatur masalah yang berhubungan dengan lingkungan hidup secara lebih terinci. Permasalahan ini dijadikan sebagai salah satu bidang dari kewenangan Pemerintah Pusat sekaligus kewenangan Daerah (provinsi) dalam bidang yang sama. Kewenangan yang dijabarkan secara teknis di dalam PP ini berarti pula ketentuan yang ada di dalam UU telah diaplikasikan dalam bentuk peraturan perundangan lebih bawah sesuai dengan prinsip peraturan perundangan yang bertata urutan dan berkelanjutan. ${ }^{\mathrm{B}}$

Menurut Pasal 2 PP No. 15 Tahun 2000 ini kewenangan pemerintah Pusat yang merepresentasikan kewenangan Negara Kesatuan mencakup kewenangan dalam bidang politik luar negeri, pertahanan keamanan, peradilan, moneter dan fiskal,

¿Lihat Hans Kelsen, General Theory of Law and Stale (New York: Russsel and Russel, 1954). Buku ini mendeskripsikan tataran norma-norma di dalam hukum berdasarkan prinsip piramida mulai dari grundnorm, norm sampai pada aturan teknis. Tataran normatif ini dijadikan sebagai dasar di dalam penyusunan produk hukum khususnya dalam hal hirarkhi peraturan perundang-undangan. Lihat pula Padmo Wahjono. 
agama serta kewenangan bidang lain. Ini adalah kewenangan dasar yang merefleksikan otoritas pemerintah pusat atas wilayah negara sebagai penjabaran dari ketentuan yang ada di atasnya. Begitu puia ketentuan yang dijabarkan, yaitu di dalam UU juga merefleksikan prinsip yang sama yaitu ketentuan yang lebih tinggi. Kewenangan bidang lain itu meliputi berbagai kebijakan yang bersifat nasional yang terinci di dalam 25 (duapuluh lima) bidang.

Berdasarkan prinsip otonomi yang bermakna kemandirian, kewenangan yang tidak disebutkan, baik kewenangan Pusat maupun provinsi itu menupakan kewenangan Kabupaten/Kota. Hakekat dari kewenangan Kabupaten/ Kota adalah residu dari kewenangan yang dimiliki oleh Pusat dan Provinsi. Rincian dari residu dimaksud ditetapkan berdasarkan Peraturan Daerah dengan ketentuan dan prinsip-prinsip yang harus dipegang di dalam hirarkhi peraturan perundang-undangan. Di antara yang terpenting adalah bahwa peraturan yang ada dibawah tidak boleh bertentangan dengan peraturan perundangan tingkat atasnya. Bahkan peraturan perundangan yang di bawah harus merupakan jabaran dari peraturan perundangan di tingkat atasnya. ${ }^{9}$

Mencermati pada kewenangan yang menjadi dasar kinerja dari Pusat dan Provinsi dalam otonomi daerah pada masalah-masalah lingkungan hidup misalnya, sebagaimana disebut di atas tentu menimbulkan berbagai masalah yang berfokus pada soal "penafsiran" atas kewenangan yang diatur. Praktiknya, kewenangan tersebut lebih sering dipandang dari sudut ekonomis. Ketika suatu urusan berkenaan dengan masalah lingkungan hidup menguntungkan dari sisi ekonomi, akan menjadi semacam perebutan kewenangan atas objeknya baik oleh Pusat, Provinsi maupun Kabupaten/Kota. Bahkan juga masyarakat yang merasa paling berhak atas objek yang akan membawa pengaruh terhadap kualitas lingkungan hidup tersebut.

Tarik ulur dari saling merasa memiliki dan merasa paling berwenang mengatur itu misalnya terjadi dalam masalah kehutanan di Kalimantan Selatan pada kasus yang dikenal dengan Tukar Guling Pegunungan Meratus. Tarik ulur atas tukar guling, sebagai refleksi dari eksploitasi hutan secara terbatas oleh PT KODECO - yang dikompensasikan dengan pemberian lahan di lokasi lain, menimbulkan permasalahan khususnya soal kewenangan. Pemerintah provinsi merasa paling berwenang karena hutan pegunungan Meratus itu membentang lintas Kabupaten. Mulai dari Hulu Sungai Utara, Hulu Sungai Tengah sampai ke Hulu Sungai Selatan. Kabupaten yang disebut-sebut itu pun merasa punya

${ }^{9}$ Asas lex posterior berbunyi: lex posterior derogat legiprioriartinya bahwa ketentuan yang lebih rendah harus tunduk dan tidak boleh bertentangan dengan aturan yang lebih tinggi tingkatannya. Prinsip ini diatur di dalam Tap No: XXMPRS/1966 tentang Memorandum DPRGR tentang Sumber Tertib Hukum dan Tata Urutan Peraturan Perundangan RI. Kendatipun sudah dinyatakan tidak beriaku oleh Tap No: III/MPR/2000 bukan berarti bahwa asas ini tidak berlaku. Sebab hakekatnya penuangan asas hukum di dalam peraturan perundang. undangan hanya sebagai refleksi dari penguatan asas dalam tataran konkret. Lihat Sudikno Mertokusumo, Penemuan Hukum (Yogyakarta. Liberty, 1996), hlm. 7 menekankan bahwa asas hukum itu ada yang dimasukkar dalam Undang Undang tetapi ada pula yang tidak sehingga menjadi asas hukum yang bersifat umum. 
wewenang dan hak atas hutan yang ada di wilayahnya.

Pada sisi lain, masyarakat yang populer disebut Suku Dayak Meratus juga merasa paling berhak atas tanah yang ditempati dengan klaim yang bersifat religius, serta argumentasi sosiokultural lainnya. Masyarakat setempat yang dimotori oleh puluhan LSM tidak menginginkan, bahkan minta agar Tukar Guling itu dibatalkan dan tidak ingin menyaksikan hutannya digunduli. Mereka melakukan tindakan demonstratif, bahkan dengan ancaman. ${ }^{10}$ Pusat melalui kebijakan nasional sebagaimana digariskan oleh Menteri Kehutanan juga mengatur masalah yang sama.

Masih banyak contoh lain yang juga muncul ke permukaan di berbagai wilayah sehubungan dengan kewenangan antara Pusat dan Daerah. Kecenderungan munculnya permasalahan itu adalah pengelolaan sumber daya alam yang menghasilkan pemasukan atau uang. Namun jika kewenangan itu sifatnya "kering", justru baik Pusat maupun Daerah cenderung saling melempar dan mengelak dari tanggungjawab. Pusat menyatakan itu kewenangan Daerah, sementara Daerah menyatakan itua dalah kewenangan Pusat."

Secara normatif, manakala muncul pergesekan kepentingan maka konstruksi yuridis yang sebenarnya menjadi tumpuan pényelesaian itu hanya diposisikan secara retorika. Kendatipun secara yuridis nampak tak ada pertentangan kepentingan namun rillnya pertentangan itu ada, baik kewenangan dari Pusat, Provinsi bahkan juga Kabupaten/Kota dan masyarakat sebagai kelompok sosial. Semua elemen itu mendasarkan diri pada perspektif otonomi. Masalahnya adalah bagaimana menyelesaikan munculnya perbedaan persepsi tentang kewenangan tersebut atas prinsip-prinsip otonomi dengan tetap berada pada koridor Negara Kesatuan RI. Bukan mustahil, pemerintah Pusat menyatakan bahwa itu kewenangannya sementara provinsi berdalih bahwa itu adalah kewenangan provinsi demikian pula pemerintah Kabupaten/Kota dan masyarakat setempat yang secara kebetulan bersinggungan langsung dengan objek lingkungan.

Kalau tidak dapat dipertemukan solusinya maka harus kembali pada institusi pengujian yaitu harus dilakukan berdasarkan prinsip

\footnotetext{
${ }^{10}$ Ancaman itu ditujukan kepada siapa saja yang melakukan eksploitasi di Pegunungan Meratus bahwa jiwanya terancam, dan masyarakat di sana akan membela hutan tempat mereka hidup itu sampai titik darah penghabisan. Ancaman itu nampaknya membuat Gubernur gentar dan menyatakan bahwa selama ini hanya tejadi kesalahan informasi. Padahal sebelumnya Gubernur dengan keras menyatakan bahwa tukar guling itu tetap akan ditindaklanjuti sesuai dengan proses formal yang telah dilalui, sebagaimana lazimnya kebijakan daerah.

${ }^{11}$ Kewenangan dalam bidang sosial, misalnya. Dalam beberapa kasus kecenderungan seperti itu mengemuka - tetapi juga ada sisi positifnya, jika menyentuh sisi yang bersifat kemanusiaan, Pusat dan Daerah justru menunjukkan simpati, melepaskan soal kewenangan dengan kebijakan saling membantu baik Pusat maupun Daerah.
} 
pengujian secara materiil (toetsingsrecht). Namun pelembagaan dari pengujian secara materiil ini masih belum memperoleh bentuk yang memuaskan. ${ }^{12}$ Akibatnya terhadap peraturan perundang-undangan yang terbit, kendatipun dimaksudkan sebagai pelaksanaan dari peraturan yang ada di atas tidak mustahil sebenarnya justru bertentangan. Hanya mekanisme untuk itu yang perlu dijernihkan sehingga bersifat operasional.

Kalau di dalam praktik selama ini pengambilan kebijakan itu lebih bersifat trial and error kiranya di masa yang akan datang tidak terjadi hal demikian. Sinkronisasi, dan bukan sekadar konsultasi pada forum yang sejajar kiranya menjadi sarana yang baik untuk hal tersebut. Tidak perlu dan tidak harus dengan cara yang ekstrem seperti ancaman memisahkan diri, menuntut prosentase pembagian tertentu yang tak sesuai dengan aturan. Justru dengan mengefektifkan forum sinkronisasi tersebut segala sesuatunya dapat diselesaikan dengan tidak menimbulkan dampak masalah berikutnya.

Demikian pula ketika muncul adanya perbedaan persepsi terhadap sebuah peraturan kiranya diselesaikan berdasar mekanisme yang ada. Dalam hal ini, Mahkamah Agung mempunyai kewenangan untuk melakukan uji materiil (judicial review) sesuai dengan ketentuan yang ada. ${ }^{13}$ Ketentuan ini mengakhiri kontroversi panjang tentang tidak dapat berfungsinya lembaga Hak Uji Materii! (HUM) yang menyebabkan beredar dan berlakunya peraturan perundangundangan yang sebenarnya bertentangan dengan peraturan yang ada di atas, sementara hukum tak berdaya menyelesaikannya. Ketakberdayaan disebabkan oleh adanya ketentuan yang mengandung contradictio in concepto. ${ }^{14}$ Kenyataan ini berlangsung sedemikian lama sehingga di dalam kinerja lembaga peradilan hanya satu kali perkara yang diajukan dengan mengacu pada ketentuan tersebut. Selebihnya banyak perkara yang kandas ketika masih berada pada proses dalam arti pemeriksaan belum menyentuh pokok perkara.

Dengan ketentuan di dalam Tap No: illl MPR/2000, sekurangnya ada harapan baru kendatipun harapan itu kecil untuk dapat tegaknya supremasi hukum dalam peraturan perundang-undangan. Dengan ketentuan tersebut, ke depan diharapkan makin banyak

${ }^{12}$ Lihat: Samsul Wahidin, Hak Uji Materiil di Indonesia (Jakarta: Cendana Press, 1984) yang menganalisis kinerja Hak Uji Materiil berdasarkan perkara yang ditangani oleh Pengadilan. Sejak diatumya masalah itu di dalam UU No. 14Tahun 1970 sampai tahun 83-an tidak ada satu perkara pun yang ditangani pengadilari berkait dengan pelaksanaan Hak Uji Materiil tersebut.

${ }^{13}$ Berdasar ketentuan di dalam Tap No: III/MPR/2000 Mah'kamah Agung secara aktif dapat melakukan uji materiil tehadap produk hukum di bawah Undang Undang dengan konsekuensi peraturan peundangan yang dinyatakan bertentangan dengan peraturan di atasnya langsung tidak berlaku. Tidak hanus menunggu pencabutan dari instansi pembuat produk hukum tersebut.

${ }^{14}$ Ketentuan Pasal 26 UU No. 14 Tahun 1970 yang mengharuskan pengujian melalui Kasasi menimbulkan permasalahan karena Kasasi harus melalui judex factie. Lalu apa yaing harus diputus oleh judex factie jika pada akhirnya yang berharga adalah keputusan kasasi? Sementara itu kalau langsung Kasasi, bukankah untuk sampai ke sana harus melalui pemeriksaan judex factie? 
masyarakat yang dapat menyalurkan rasa ketidakadilan akibat dikeluarkannya kebijakan di dalam peraturan perundang-undangan khususnya pada level di bawah Undang Undang. Hal itu secara langsung akan menjadi sumbangan berharga bagi tegaknya supremasi hukum terutama pada level instrumen yaitu peraturan perundangundangan. Tentu akan menjadi pelajaran berharga bagi para pencetus kebijakan.

Masalahnya dalam soal operasionalisasi kewenangan ini, sering muncul perbedaan tafsir antara (aparat) Pusat dan (aparat) daerah yang didasari oleh kepentingan serta orientasi yang masing-masing merasa benar. Apa lagi menyangkut permasalahan yang sarat dengan kepentingan politik dan ekonomi. Paradigma yang seharusnya dikedepankan atas dasar koordinatif sering berubah menjadi instruktif. Sementara instruksi yang disampaikan (oleh Pusat) kepada Daerah, dalam beberapa peristiwa justru tidak diindahkan. Hal ini yang kemudian semakin menumbuhkan friksi dan bahkan memunculkan konfilik kepentingan di antara Pusat dan Daerah.

Penyelesaian yang semestinya dilakukan adalah berdasarkan hukum, khususnya peraturan perundangan yang secara konsisten telah dipatok untuk itu. Akan tetapi disadari bahwa hukum memang hanya salah satu instrumen. Masih ada lagi instrumen lain baik yang bersifat administratif maupun pendekatan yang bersifat negosiasi tetapi sifatnya hanya sementara. Ke depan akan muncul permasalahan baru kalau tidak didasarkan atas penyelesaian secara hukum. Hal itu disebabkan bahwa pada dasarnya penyelesaian yang dilakukan di luar hukum cenderung temporer dan dampaknya pun tidak langgeng. Belum lagi pada elemen kepastian hukum yang menjadi taruhan yaitu terjadinya degradasi hukum manakala penyelesaian non hukum yang ditempuh.

Memahami mengapa hal di atas dapat terjadi karena baik di daerah maupun di Pusat ada lembaga yang secara langsung juga menangani permasalahan yang sejatinya sama. Sementara di Daerah pun ada lembaga yang sejenis yang juga merasa punya kewenangan dalam masalah yang sama. Sebagai contoh, di dalam bidang lingkungan hidup, misalnya. Ada Bapedalda, baik di tingkat provinsi maupun Kota/Kabupaten, di samping lembaga lain yang secara strukturanl menangani permasalahan lingkungan. Belum lagi elemen dalam masyarakat yang diwakili oleh LSM dalam jumlah yang banyak dan beragam. Dalam kaitan ini sangat diperlukan adanya penanganan secara lebih terpadu dalam arti setiap tindakan yang akan mempergunakan dasar-dasar kebijakan lingkungan, demikian pula untuk penggarisan kebijakan pada level darah senantiasa memperhatikan hirarkhi peraturan perundangan secara konsisten dan konsekuen.

Sejatinya, yang menjadi kata kunci terhadap keberhasilan pelaksanaan dan penegakan hukum adalah konsistensi. Konsistensi ini harus menjadi komitmen aparat pelaksana mulai dari tingkat Pusat sampai ke Daerah tanpa kecuali. Secara lebih terperinci, konsistensi dimaksud meliputi konsistensi dalam hal tindakan praktis atau implementasi dan penggarisan kebijakan. Kedua hal ini kiranya sangat penting dalam hal menciptakan sinkronisasi penanganan permasalahan lingkungan hidup, khususnya antara Pusat dan Daerah.

Dalam hal tindakan, upaya yang seringkali disebut sebagai terobosan kiranya tidak 
dilakukan. Harus senantiasa konsisten pada peraturan yang dibuat kendatipun hal itu kemungkinan membawa kerugian materi. Namun harus senantiasa diingat bahwa.kerugian lebih besar di kemudian hari, jika sebuah terobosan dilakukan akan tejadi serta harus dibayar dengan biaya lebih mahal. Bukan hanya kerugian materi yang lebih besar akan tetapi juga terdegradasinya tingkat kepercayaan terhadap hukum oleh masyarakat. Padahal tingkat kepercayaan ini adalah asset tak ternilai mahal serta besarnya dari kinerja penegakan hukum di masyarakat.

Penggarisan kebijakan tersebut, khususnya di daerah harus secara konsisten berpegang pada aturan yang jelas. Kejelasan ini sekurangnya tidak menimbulkan biinterpretasi (dua penafsiran), apa lagi yang bersifat poliinterpretasi (multipenafsiran) sehingga lebih mengacaukan institusi yang dengan susah payah diciptakan. Institusi dimaksud, di antaranya adalah penyempurnaan terhadap hirarkhi peraturan perundangan sebagaimana tertuang di dalam Tap No: III/MPR/2000 sehingga berbagai permasalahan yang berhubungan dengan konflik norma, kekosongan hukum dan kekaburan yang terjadi sebagai akibat ketakjelasan peraturan dapat dihindarkan.

\section{Simpulan}

Perspektif sinkronisasi produk hukum antara Pusat dan Daerah -apakah produk hukum (peraturan perundangan) itu mengandung pertentangan (konflik) atau tidak tergantung pada berbagai komponen yang saling terkait. Terpenting dari itu semua adalah bagaimana law enforcement terhadap ketentuan yang berhubungan dengan pengujian, dapat dilaksanakan secara baik. Ada atau tidaknya peraturan yang berpotensi mengandung konflik baik vertikal maupun horizontal lebih cenderung pada sikap kritis komponen masyarakat untuk membuktikan sesuai dengan ketentuan yang telah dibuat. Konsistensi terhadap penegakan hukum adalah langkah positif dalam perspektif penegakan hukum. Prejudice terhadap ketentuan hukum yang dinilai berpotensi mengandung konflik, tanpa peduli dengan kinerja yang seharusnya ditempuh, merupakan indikator negatif di dalam penegakan hukum.

\section{Daftar Pustaka}

Anonim. Webster's New Collegiate Dictionary. USA: Tp, Tt

Koesoemahatmadja, RDH. Pengantarke Arah Sistem Pemerintahan Daerah di Indonesia. Bandung. Binacipta, 1979

Friedrich, CJ. Man and His Government. New. York: Mc Graw Hill, 1976.

Riggs, Fred.W. Administrasi Pemerintahan (tejemahan). Jakarta. Rajawali Press, 1993.

Atmosudirdjo, Prajudi. Hukum Administrasi Negara. Bandung. Alumni, 1978.

Hadjon, Philipus M. Pengantar Hukum Administrasi, Yogyakarta. Gajahmada University Press, 1995.

Pot, CW Van der. Handboek van Nederlans Staatsrecht. 1953. 
Sjarief, Saleh. Otonomi dan Daerah Otonom.. Jakarta: Pustaka, 1953.

Istanto, Sugeng. Beberapa Segi Hubungan Pemerintah Pusat dan Daerah dalam Negara Kesatuan Indonesia. Yogyakarta: Karyaputra, 1971.

Larenz, Karl. Methodenlehre der Rechtswissenschaft. Berlin: Springer Verlag, 1983.

Lubis, M. Solly. Pergeseran Garis Politik dan Perundang Undangan Mengenai
Pemerintahan Daerah. Bandung: Alumni, 1975.

Viarda, GJ. Drie Typen van Rechtsvinding. Tjeenk Willink-Zwole, 1980.

Koesoemahatmadja, Djenal Hosen Pemerintahan Lokal. Bandung: Alumni, 1983.

Pontier, J.A. Rechtsvinding. Nijmegen: Ars Aequi Libri, 1988.

\section{வ 26}

